\title{
CAREER PATH PLANNING AND ITS IMPACT ON PREPARING AND QUALIFYING FUTURE LEADERS: FIELD STUDY ON SOME CORPORATIONS WORKING IN BUILDING, CONSTRUCTING AND MAINTENANCE OF SHIPS IN EGYPT
}

\section{Amira Said Mohamed Gadelrab}

Faculty of commerce, Suez Canal University Ismailia, Egypt ABSTRACT:

The research purpose is to analyse the relation between career path planning and preparing the future leaders. The sample is the 278 units and the researcher use the regression analysis to analyse the data. The research hypotheses are four hypotheses of the measurement of the main variables. The finding there is a relation between the independent variable and dependent one.

KEYWORDS: Career, Career path planning, employees awareness, career progression

\section{INTRODUCTION}

The dredging of the canal took almost 10 years using Egyptian labor, and it was opened for navigation for the first time in 17 November 1869. Its depth was about 8 meters, its water are was $304 \mathrm{~m} 2$ and the largest ship load that can pass through was 5000 tons, which was typical for ships

$$
\text { r.r. العدد الثالث الجزء الثاني }
$$$$
\text { المجلد الحادي عشر }
$$ 
sizes in these days. As the ships developed and increased its sizes, the canal needed to be developed, which happened when it was still a foreign joint venture before being publicized to take ships with depth of 35 feet and its water area to be $1200 \mathrm{~m} 2$ by the end of 1956 and when the canal was publicized by the Egyptian government on the 26th of July 1956. The Egyptian administration was keen to develop the Navigation canal even more on different stages.

In May 1962, the water area of the canal was to reach 1800 m 2 and the allowed depth to 38 feet. In June 1966, a development was to be executed on 2 stages as it was announced the depth would reach 48 and 58 feet consecutively. This program was started, but was soon halted due to the war that erupted on the 5th of June, 1967. It was reopened for international; navigation in June 1975 after purifying it from the ships that sank in its bottom during in the 1967 and 1973 wars, The canal still with the same water area and depth as before it was closed.

The development projects then started by the Egyptian administration and received to ships of a 210,000 tons load, especially after increasing the water area to $4800 \mathrm{~m} 2$ and a ship draft of 62 feet, with a length of $191.80 \mathrm{~km}$, in addition to the redesign of the canal's turns so that each one has a radius of at least $5000 \mathrm{~m}$ and also dredging a new bypass starting from the 17th $\mathrm{km}$ south of port said heading directly 
to the Mediterranean east of port Fouad to allow the loaded ships going north to go to the sea without passing through port said port.

The ship draft reached 66 feet by 2010, this stage taking all container vessels; about 17,000 container vessels; as well as taking all bulk vessels worldwide. The Canal will be able to take in about $99 \%$ of all methods used in world maritime transport after reaching a depth of 72 feet (Target stage,Under Study), as well as taking about $96.2 \%$ of the dead weight tons for the bulk

vessels $80.3 \%$ of the petroleum tanks and a $100 \%$ of all the remaining types of ships used in maritime transport; specially container vessels with all its future generations; in addition to empty vessels reaching up to 440 thousand tons.

One of the strongest companies in suez canal is Suez Shipyard company and ElTemsah company, where Temsah company was published at 1961 . the employees at the company were 1378 labors and technicians . the company owns two arsenals at Ismailia and Aboer at Alexandria the following is the main activities :

* Building of different types of vessels, marine units, tugs, fast service launches, passenger boats and lash boats.

* Specialized in the design, construction and maintenance of all types of mooring systems, platforms for oil industry, 
beacons, dolphins, pilot \& Light buoys, sea berths and quays.

* Formatting and construction of all steel works such as: fuel \& water tanks, pipelines, siphons and barley \& corn storage silos.

* Ship repairs (docking of floating units up to 1500 tons for maintenance and repair).

* Renting marine units and tugs to oil companies

* Dredging works.

* Carrying out underwater welding \& cutting operations by a well-equipped and qualified salvage team who obtained IMCA certificate The second company is suez shipyard which is the main activities are the following:

Repair and maintenance of ships and different marine units transiting the Suez Canal, as the company owns a floating dock (up to 55000 tons), a dry dock (up to 800 tons) and synchrolift of 900 tons lifting capacity.

* Building of marine units (floating cranes, barges).

* Manufacturing and installation of steel structures such as: lighting towers, tanks, hangers, storage silos and marine scaffolds.

العدد الثالث الجزء الثاني •r.r.

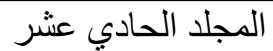


* Manufacturing and maintenance of pipelines of all diameters.

* Installation of water and sewage pipes.

* Manufacturing pontoons and dredging discharge pipes in addition to maintenance of dredging equipment.

* Manufacturing fibre glass mill blades.

\section{LITERATURE REVIEW}

1- Career path planning:

The career is all the jobs that are held during ones working life. According to E.B. Flippo', career is a sequence of separate but related work activity's that provides continuity, order and meaning in a person's life. (Dwivedi \& Mahila, 2017) . First of all, it is necessary to distinguish between a job and a career. Definitions of a career suggest the idea of an occupation chosen as the means of one's progress through life.( Farmer, Ward \& wood, 1996). During the last few decades, career planning and management has appeared to be one of the fastest developing areas in the field of human resource management (HRM).

This holds true for theoretical research as well as practical purposes (Baruch,1996). Career planning starts from the

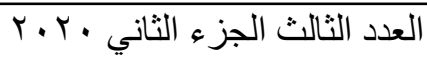
المجلد الحادي عشر 
basic assumption that a person starts to work after placement in an organization will continue to work for the organization until he retires. (Triandani \&Anggriani , 2009). Mangkuprawira (2002) stated, "the career path planning is a sequential pattern of work that make up one's career". An important aspect of career planning is to establish the extent to which the two parties (individuals and organizations) are responsible in this process. On one hand, the individual is responsible for its development along the stages of his life and, secondly, the organization involved in planning and development of career helps to improve the organizational environment and enhance employee satisfaction at work. (ANTONIU ,2010). Puah and Ananthram (2006) have identified career planning and career management as the two main antecedents of career development. The integration of both employees' career planning and organizational career management practices result in effective career development (Hall, 1986).

Career planning, career management and career development are overlapping terms sometimes used interchangeably in the research literature, by practitioners, and by workers and employers themselves. Both individuals and organisations engage in all three processes, although they have somewhat different motivations, practices and expected outcomes. (creed \& Hood, 2009).

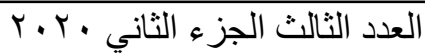

المجلد الحادي عشر 
CAREER PATH PLANNING AND ITS IMPACT ON PREPARING ...

Dr/ Amira Said Mohamed Gadelrab

Career Development Is A Process Where An Employees Wants And Increase In Its Work. The Increase Includes The Increase Of Position Authority And Responsibility. Clear Career Advancement System Will Motivate Employees To Work Harder So That They Performance Will Increase Which Will Directly Have A Good Impact For The Employees. (Triandani \& Anggriani , 2015).

Career path is the way that demonstrates a series positions in an incremental outline in which the worker moves and support through his career life in the association (Eliza, 2010, 1). Career path defines as the succession of job experiences that position an individual for advanced rank jobs (Stewart and Brown, 2011, 381).

In human resource management, career planning aims to identify needs, aspirations and opportunities for individuals' career and the implementation of developing human resources programs to support that career. According to Edgar Schein career planning (Manolescu, 2003) is a continuous process of discovery in which an individual slow develops his own occupational concept as a result of skills or abilities, needs, motivations and aspirations of his own value system .

Career pathways are connected systems of education and training programs that build upon one another to help a 
person enter and advance in his/her career in an industry. Pathways are business-defined and business-driven and aligned to the skill needs of targeted industry sectors and are explicitly focused on helping people more easily and quickly enter into and advance in their careers. In many cases, career pathways are an example of a priority industry sector strategy pursued by sector partnerships. (pathways , 2018).

Career planning, career management and career development are overlapping terms sometimes used interchangeably in the research literature, by practitioners, and by workers and employers themselves. Both individuals and organisations engage in all three processes, although they have somewhat different motivations, practices and expected outcomes. Here we briefly outline, from the organisational perspective, individual career planning, management and development, in which, nevertheless, it will be seen, the organisation plays a major role. The following section focuses on organisational career planning, management and development which, for convenience, we subsume under the heading of organisational career management (Baruch \& Peiperl, 2000).

\section{Leadership}

The millennial leader will change leadership, just as the generation is beginning to change what it needs from 
companies, careers and leaders. For many millennials, their first job is out of college, leaving the list of job experience little to none. The common practice currently in promoting leaders is that the right leader is someone who has the "right" list of experiences combined with the "right" personality characteristics. So what will a successful leader look like? Good leadership and how the definition of a good leader can be elusive, but in almost every article, book, journal entry, magazine and blog leadership success if defined by the ability of a leader to identify, sustain and inspire other talented people (Bennis and Thomas, 2007, p. 10). With that being the foundation of success, curiosity and belief will lend themselves to continued success in current leaders as well as be the traits that can be passed on to the leaders of the future. (Akers ,2015).

Today's work environment requires a new type of leader development. It is no longer enough for leaders to be qualified and knowledgeable. Leaders must be focused, adaptable, and resilient in order to be effective amid the increasingly distracting and chaotic organizational world. We argue that current methods of leader development need to evolve to encompass leader well-being and focus on intrapersonal competencies in order to adequately prepare leaders for today's stressful work world. We provide a holistic development framework for leaders which we 
believe is a better match for the intrapersonal capabilities required by leadership roles. Our approach is two-fold. First, we believe it is important to edu- cate leaders on the potential interaction between the external sources of stress and leaders' neurophysiological and subjective well-being. Second, we believe leaders need different development experiences, ones that can help renew psychological resources. We review four categories of holistic (Clerkin \&Ruderman ).

The LDP offers opportunities for developing young engineer and technologist's character and interpersonal skills to become leaders in their field. Additionally, the LDP provides students with the opportunity to learn from manufacturing executives, tour world-class manufacturing companies, and participate in workshops designed to develop their leadership skills, social etiquette, and business decorum. From an institutional perspective, it strengthens existing relationships between the university and community colleges, which may positively affect future transfer numbers. Because the selected cohorts are strong academically; retention, graduation, and job placement rates are also likely to rise, thereby increasing the number of high-quality graduates entering the engineering workforce. Such visible success will in turn strengthen partnership opportunities between the university and the hiring industry. 
(palmer, Neuhoff \& kowlchulf, 2015)

\section{Research problem}

AS the field study is on Timsah Shipbuilding Company and the Suez shipyard has some problems related to the career path planning and leadership. Timsah shipbuilding has no planning for the career path along with all levels of management as the company was established at 1961 and its home business at Ismailia and it is one of the suez canal companies and the employees at this company is 1378 labors and technical and the suez shipyard has no plans for preparing future leaders as this company one of the sue canal companies and was established at 1963 and its one of the most important companies in repairing ships in red sea area so the problem of the research will be as follow:

"there is a shortage in two companies in applying the concept of career path planning and preparing future leadership and this will be the focus of this research". 
CAREER PATH PLANNING AND ITS IMPACT ON PREPARING ...

Dr/ Amira Said Mohamed Gadelrab

\begin{tabular}{|l|l|}
\hline Independent variable & Dependent variables \\
\hline Stating career path purposes & Top management strategic direction \\
\hline Employee awareness for career path & Future leaders IT \\
\hline Career progression opportunities & Innovative and creative training \\
\hline Career path development & Succession planning \\
\hline
\end{tabular}

Table 1

RESEARCH METHODOLOGY

\section{Research design}

The researcher used two types od data sources as follows:

\section{Secondary data}

The data that has been used to achieve the research purposes upon the research problem and variables as the researcher depend in formulating the theoretical background on the arabic and English books and scientific journals and periodicals and the specific published and un published research

\section{Primary data}

The data has been collected from all levels of management in Temsah company and Shipyard Company through questionnaire to collect the sample opinions and attitude which serve the research topic and this to test the 
hypotheses in addition to make some interviews and this according to the following:

1- Questionnaire : the questionnaire was designed to know the employees attitude at both Temsah and Shipyard companies at Egypt and the questionnaire formulated to conclude all the research variables which classified into 2 sections :

First part: questions related to career path planning indicators and consist of 20 statement. Second part: questions related to preparing future leaders and consist of 20 statement.

2- Interviews: the researcher held interviews to analyze the questionnaire to understand interviewees' responses and get some information, data, notes and opinions from interviewees. 3- Analytical study: questionnaire was collected, classified and categorized to be analyzed and explained to summarize the result and recommendations.

Research population and sample

1- Research population :

The research population represent the employees in top and middle level of management at Temsah and Shipyard companies which represent 624 according to data at 2018 .

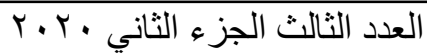

المجلد الحادي عشر 
2- $\quad$ Research sample:

The research used sample form top and middle management at the Temsah and Shipyard companies at Egypt, therefore stratified random sample was selected at significant level 95\% and error 5\% and the sample was stated according to the equation

Through solving this equation the sample will be 237.775 units Reliability and validity test

The validity test for every indicator in the research greater than .60 and the validity test for questionnaire was .842 which make the questionnaire specified with high level of validity. The reliability test for all indicators greater than .60 and for all the questionnaire was 0.918 which specified the questionnaire with high degree of reliability .

\begin{tabular}{|l|l|l|l|l|}
\hline No. & Indicators & Validity & reliability & $\begin{array}{l}\text { Statement } \\
\text { Numbers }\end{array}$ \\
\hline 1 & Stating career path purposes & 0.822 & 0.907 & 5 \\
\hline 2 & Employee awareness for career path & 0.787 & 0.887 & 5 \\
\hline 3 & Career progression opportunities & 0.854 & 0.924 & 5 \\
\hline 4 & Career path development & 0.705 & 0.840 & 5 \\
\hline 5 & Top management strategic direction & 0.861 & 0.928 & 5 \\
\hline
\end{tabular}

العدد الثالث الجزء الثاني • r. r

المجلد الحادي عشر 
CAREER PATH PLANNING AND ITS IMPACT ON PREPARING ...

Dr/ Amira Said Mohamed Gadelrab

\begin{tabular}{|l|l|l|l|l|}
\hline 6 & Future leaders IT & 0.872 & 0.934 & 5 \\
\hline 7 & Innovative and creative training & 0.889 & 0.934 & 5 \\
\hline 8 & Succession planning & 0.806 & 0.898 & 5 \\
\hline & Overall questionnaire & 0.842 & 0.898 & 40 \\
\hline
\end{tabular}

Table2

Research limitations

- Human Limitation: the field study include all employees in middle and top management level at both companies ElTemsah and suez shipyard at Egypt .

- Spatial limitation: the study was applied on all branches of Temsah and Shipyard companies at Egypt .

- Time limitation: the information and data was collected through 2018

\section{Hypotheses test:}

The Null hypothsis for the study is " there is no significant relation between career path planning and preparing future leaders and this hypothesis classified into the following two sub hypotheses:

1- There is no significant relation between career path planning goals and preparing future leaders and to test this hypothesis the following test has been performed : 
a- Correlation coefficient :

The following table clarify the correlation coefficient between identifying career path planning goals as independent variable and preparing future leaders as dependent variable

\begin{tabular}{|c|c|c|c|}
\hline $\begin{array}{c}\text { Preparing future } \\
\text { leaders }\end{array}$ & $\begin{array}{c}\text { Identifying career } \\
\text { path planning }\end{array}$ & Test & Variable \\
\hline 0.558 & 1 & Pearson Correlation & $\begin{array}{c}\text { Identifying career } \\
\text { path planning }\end{array}$ \\
\hline 0.000 & 00000 & Sig. & . \\
\hline
\end{tabular}

Table3

The preceding table clarify that there is significant correlation at percent of $55.8 \%$ at significant level .05 between the two variables .

b- The coefficient of deterimination:

\begin{tabular}{|c|c|c|c|}
\hline $\begin{array}{c}\text { Std. Error of the } \\
\text { Estimate }\end{array}$ & $\begin{array}{c}\text { Adjusted R } \\
\text { Square }\end{array}$ & R Square & Independent variable \\
\hline 11.24064 & 0.308 & 0.312 & $\begin{array}{c}\text { Identifying career path } \\
\text { planning goals }\end{array}$ \\
\hline
\end{tabular}

Table4

The preceding table clarify that coefficient of deterimination $\mathrm{R}^{2}$ is .312 which mean that identifying career path goals explain preparing future leaders at percent of $31.2 \%$, the remaining percent explained by other variables not included 
in the relation in addition to random error as aresult to sample collection and measurement accuracy.

c- ANOVA test

\begin{tabular}{|c|c|c|c|c|c|}
\hline Sig. & F & Mean Square & Df & $\begin{array}{c}\text { Sum of } \\
\text { Squares }\end{array}$ & Model \\
\hline \hline \multirow{2}{*}{0.000} & \multirow{2}{*}{88.389} & 11168.19 & 1 & 11168.189 & Regression \\
\cline { 3 - 7 } & & 126.352 & 195 & 24638.644 & Residual \\
\cline { 3 - 6 } & & 196 & 35806.832 & Total \\
\hline
\end{tabular}

Table 5

The preceding table clarify that there is a positive relation between two variables and this abvious from value of $\mathrm{F}$ which is at significant level .05 which clarify the presence of relation between the two variables .

d- Regression analysis :

\begin{tabular}{|l|l|l|l|l|l|l|}
\hline \multirow{2}{*}{ Sig. } & \multirow{2}{*}{$\mathrm{T}$} & $\begin{array}{l}\text { Standardized } \\
\text { Coefficients }\end{array}$ & \multicolumn{2}{|l|}{$\begin{array}{l}\text { Unstandardized } \\
\text { Coefficients }\end{array}$} & \multirow{2}{*}{ Model } \\
\cline { 4 - 6 } & Beta & Std. Error & $\mathrm{B}$ & \\
\hline 0.000 & 5.62 & & 4.133 & 23.229 & Constant & 1 \\
\cline { 4 - 6 } 0.000 & 9.402 & 0.558 & 0.25 & 2.348 & $\begin{array}{l}\text { Identifying } \\
\text { career } \\
\text { Path planning } \\
\text { goals }\end{array}$ & 1 \\
\hline
\end{tabular}

Table6

The preceding table clarify that value of $\mathrm{T}$ for all statements od

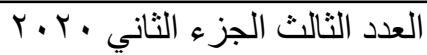
المجلد الحادي عشر 
independent. Variable at significant level of .05 which represent the strong relation between the two variables .

From the table researcher can summarize the following:

- $\quad$ The significant level of pearson and regression less than .05 which stated a relation between the two variables .

- The sign of pearson is positive which stated positive relation between two variables .

- $\quad$ From ANOVA test result researcher can generalize the result .

- Beta indicated that identifying career path planning goals influence preparing future leaders at different percentages and this explanation not by chance .

From preceding the researcher can accept the alternative hypothesis there significant relation between the two variables .

The second sub-hypothesis:

There is no significant relation between employee awareness of career path on preparing future leaders .

To test this hypothesis the researcher perform the following: a- Correlation 
CAREER PATH PLANNING AND ITS IMPACT ON PREPARING ...

Dr/ Amira Said Mohamed Gadelrab

\begin{tabular}{|c|c|c|c|}
\hline $\begin{array}{c}\text { Preparing future } \\
\text { leaders }\end{array}$ & $\begin{array}{c}\text { Employee awareness } \\
\text { Of career path } \\
\text { planning }\end{array}$ & Test & Model \\
\hline 0.643 & 1 & $\begin{array}{c}\text { Pearson } \\
\text { Correlation }\end{array}$ & $\begin{array}{c}\text { Employee } \\
\text { awareness of } \\
\text { career path }\end{array}$ \\
\hline 0.000 & 00000 & Sig. & \multicolumn{2}{|c}{} \\
\hline
\end{tabular}

Table 7

The preceding table clarify that there is a correlation at

$64.3 \%$ at significant level .05 between the two variables .

b- Coeffiicient of deterimination :

\begin{tabular}{|c|c|c|c|}
\hline $\begin{array}{c}\text { Std. Error of the } \\
\text { Estimate }\end{array}$ & $\begin{array}{c}\text { Adjusted R } \\
\text { Square }\end{array}$ & R Square & Model \\
\hline \hline 10.38071 & 0.411 & 0.413 & $\begin{array}{c}\text { Employee awareness of } \\
\text { career path }\end{array}$ \\
\hline
\end{tabular}

Table8

The table present that the coefficient of deterimination .413 which indicate that independent variable explain dependent one by $41.3 \%$.

\section{c- ANOVA test:}

\begin{tabular}{|c|c|c|c|c|c|}
\hline Sig. & F & Mean Square & Df & $\begin{array}{c}\text { Sum of } \\
\text { Squares }\end{array}$ & Model \\
\hline \hline \multirow{3}{*}{0.000} & \multirow{3}{*}{137.286} & 14793.79 & 1 & 14793.79 & Regression \\
\cline { 3 - 6 } & & 107.759 & 195 & 21013.04 & Residual \\
\cline { 3 - 6 } & & 196 & 35806.83 & Total \\
\hline
\end{tabular}

Table9

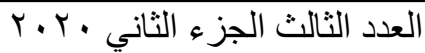


There is positive relation between two variables which presented from value of $\mathrm{F}$ at significant level .05 .

d- Regression analysis :

\begin{tabular}{|c|c|c|c|c|c|}
\hline \multirow[t]{2}{*}{ Sig. } & \multirow[t]{2}{*}{$\mathrm{t}$} & \multirow{2}{*}{$\begin{array}{l}\text { Standardized } \\
\text { Coefficients } \\
\text { Beta } \\
\end{array}$} & \multicolumn{2}{|c|}{$\begin{array}{l}\text { Unstandardized } \\
\text { Coefficients }\end{array}$} & \multirow[t]{2}{*}{ Model } \\
\hline & & & Std. Error & B & \\
\hline 00000 & 5.759 & & 3.563 & 20.518 & Constant \\
\hline 0.000 & 11.717 & 0.643 & 0.223 & 2.608 & $\begin{array}{l}\text { Employee } \\
\text { awareness }\end{array}$ \\
\hline
\end{tabular}

Table10

The preceding table clarify that value of $\mathrm{T}$ for all statements to independent. Variable at significant level of .05 which represent the strong relation between the two variables .

From the table researcher can summarize the following:

- The significant level of pearson and regression less than .05 which stated a relation between the two variables .

- The sign of pearson is positive which stated positive relation between two variables .

- $\quad$ From ANOVA test result researcher can generalize the result .

- $\quad$ Beta indicated that identifying career path planning goals influence preparing future leaders at different percentages and this explanation not by chance . 
- $\quad$ From preceding the researcher can accept the alternative hypothesis there significant relation between the two variables .

2- $\quad$ The third sub- hypothesis :

There is no significant relation between career development opportunity on preparing future leaders .

To test the hypothesis the researcher perform the following:

a- Correlation :

\begin{tabular}{||l|l|l|l||}
\hline $\begin{array}{l}\text { Preparing future } \\
\text { leaders }\end{array}$ & $\begin{array}{l}\text { Career progression } \\
\text { opportunity }\end{array}$ & Test & Model \\
\hline \hline 0.683 & 1 & $\begin{array}{l}\text { Pearson } \\
\text { Correlation }\end{array}$ & $\begin{array}{l}\text { Career } \\
\text { progression } \\
\text { opportunity }\end{array}$ \\
\hline 0.000 & 00000 & Sig. & \multicolumn{2}{|l}{} \\
\hline
\end{tabular}

\section{Table11}

The preceding table clarify that there is a correlation at $68.3 \%$ at significant level .05 between the two variables .

b- Coefficient of deterimination :

\begin{tabular}{|l|l|l|l|}
\hline $\begin{array}{l}\text { Std. Error of the } \\
\text { Estimate }\end{array}$ & $\begin{array}{l}\text { Adjusted R } \\
\text { Square }\end{array}$ & R Square & Model \\
\hline \hline 9.89486 & 0.464 & 0.467 & $\begin{array}{l}\text { Career progression } \\
\text { opportunity }\end{array}$ \\
\hline
\end{tabular}

\section{Table12}

The table present that the coefficient of deterimination .467 which indicate that independent variable explain dependent one 
by $46.7 \%$.

c- $\quad$ ANOVA

\begin{tabular}{|l|l|l|l|l|l|}
\hline Sig. & F & Mean Square & Df & Su of Squares & Model \\
\hline \hline \multirow{3}{*}{0.000} & \multirow{3}{*}{170.718} & 16714.71 & 1 & 16714.71 & Regression \\
\cline { 3 - 6 } & & 97.908 & 195 & 19092.12 & Residual \\
\cline { 3 - 6 } & & 196 & 35806.83 & Total \\
\hline
\end{tabular}

Table13

There is positive relation between two variables which presented from value of $\mathrm{F}$ at significant level .05.

d- Regression analysis

\begin{tabular}{||l|l|l|l|l|l||}
\hline \multirow{2}{*}{ Sig. } & \multirow{2}{*}{$\mathrm{T}$} & $\begin{array}{l}\text { Standardized } \\
\text { Coefficients }\end{array}$ & \multicolumn{2}{|l|}{$\begin{array}{l}\text { Unstandardized } \\
\text { Coefficients }\end{array}$} & \multirow{2}{*}{ Model } \\
\cline { 4 - 5 } & & Beta & Std. Error & $\mathrm{B}$ & \\
\hline 00000 & 6.819 & & 3.138 & 21.397 & Constant \\
\cline { 4 - 6 } 0.000 & \multirow{2}{*}{13.066} & \multirow{2}{*}{0.683} & 0.198 & 2.583 & $\begin{array}{l}\text { Career } \\
\text { progression } \\
\text { opportunity }\end{array}$ \\
\hline
\end{tabular}

Table14

The preceding table clarify that value of $\mathrm{T}$ for all statements to independent. Variable at significant level of .05 which represent the strong relation between the two variables.

From the table researcher can summarize the following:

- The significant level of pearson and regression less than .05 which stated a relation between the two variables .

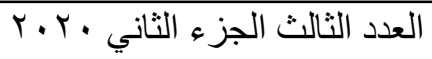$$
\text { المجلد الحادي عشر }
$$ 
- The sign of pearson is positive which stated positive relation between two variables .

- $\quad$ From ANOVA test result researcher can generalize the result .

- $\quad$ Beta indicated that identifying career path planning goals influence preparing future leaders at different percentages and this explanation not by chance .

- $\quad$ From preceding the researcher can accept the alternative hypothesis there significant relation between the two variables .

3- Forth sub-hypothesis:

There is no significant relation between career path expansion and preparing future leaders . To test the hypothesis the researcher perform the following :

a- Correlation:

\begin{tabular}{|c|c|c|c|}
\hline $\begin{array}{c}\text { Preparing future } \\
\text { leaders }\end{array}$ & Career path expansion & Test & Model \\
\hline \hline 0.612 & 1 & Pearson Correlation & $\begin{array}{c}\text { Career path } \\
\text { development }\end{array}$ \\
\hline 0.000 & 00000 & Sig. & \multicolumn{2}{|c}{} \\
\hline
\end{tabular}

Table 15

The preceding table clarify that there is a correlation at $61.2 \%$ at significant level .05 between the two variables . b- Coefficient of determination :

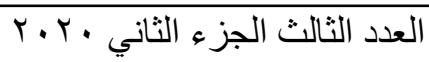
المجلد الحادي عشر 
CAREER PATH PLANNING AND ITS IMPACT ON PREPARING ...

Dr/ Amira Said Mohamed Gadelrab

\begin{tabular}{|c|c|c|c|}
\hline $\begin{array}{c}\text { Std. Error of the } \\
\text { Estimate }\end{array}$ & Adjusted R Square & R Square & Model \\
\hline 10.72162 & 0.371 & 0.374 & Career path development \\
\hline
\end{tabular}

Table 16

The table present that the coefficient of deterimination .374 which indicate that independent variable explain dependent one by $37.4 \%$.

c- ANOVA:

\begin{tabular}{|c|c|c|c|c|c|}
\hline Sig. & F & Mean Square & Df & Sum of Squares & Model \\
\hline \hline \multirow{3}{*}{0.000} & \multirow{3}{*}{116.49} & 13390.96 & 1 & 13390.96 & Regression \\
\cline { 3 - 6 } & & 114.953 & 195 & 22415.88 & Residual \\
\cline { 3 - 6 } & & 196 & 35806.83 & Total \\
\hline
\end{tabular}

\section{Table17}

There is positive relation between two variables which presented from value of $\mathrm{F}$ at significant level .05.

d- Regression analysis:

\begin{tabular}{|c|c|c|c|c|c|}
\hline \multirow[t]{2}{*}{ Sig. } & \multirow[t]{2}{*}{$\mathrm{t}$} & $\begin{array}{c}\text { Standardized } \\
\text { Coefficients }\end{array}$ & \multicolumn{2}{|c|}{$\begin{array}{c}\text { Unstandardized } \\
\text { Coefficients }\end{array}$} & \multirow[t]{2}{*}{ Model } \\
\hline & & Beta & Std. Error & $\mathrm{B}$ & \\
\hline 00000 & 3.881 & & 4.232 & 16.424 & Constant \\
\hline 0.000 & 10.793 & 0.612 & 0.257 & 2.769 & $\begin{array}{l}\text { Career path } \\
\text { Development }\end{array}$ \\
\hline
\end{tabular}

Table 18

The preceding table clarify that value of $\mathrm{T}$ for all statements to 
independent. Variable at significant level of .05 which represent the strong relation between the two variables .

From the table researcher can summarize the following:

- The significant level of pearson and regression less than .05 which stated a relation between the two variables .

- The sign of pearson is positive which stated positive relation between two variables .

- $\quad$ From ANOVA test result researcher can generalize the result .

- $\quad$ Beta indicated that identifying career path planning goals influence preparing future leaders at different percentages and this explanation not by chance .

From preceding the researcher can accept the alternative hypothesis there significant relation between the two variables.

From the preceding analysis the four sub hypotheses has been rejected so the Null hypothesis has been rejected and accept the alternative one "there is significant relation between career path planning and preparing future leaders " The second Hypothesis:

There is no significant differences between sample opinions in ELTEMSAH company and suez Shipyard company on 
CAREER PATH PLANNING AND ITS IMPACT ON PREPARING ...

Dr/ Amira Said Mohamed Gadelrab

preparing future leaders the following table represent the analysis:

\begin{tabular}{|c|c|c|c|c|c|}
\hline$\overline{\text { Significant }}$ & $\begin{array}{l}\text { Test } \\
\text { value }\end{array}$ & $\begin{array}{l}\text { Standard } \\
\text { deviation }\end{array}$ & Mean & & Field \\
\hline \multirow[b]{2}{*}{0.023} & \multirow[b]{2}{*}{5.290} & 0.58 & 3.18 & Temsah & \multirow[t]{2}{*}{$\begin{array}{c}\begin{array}{c}\text { Identifying career } \\
\text { path goals }\end{array} \\
\text {. }\end{array}$} \\
\hline & & 0.69 & 3.30 & Suez shipyard & \\
\hline \multirow[b]{2}{*}{0.000} & \multirow[b]{2}{*}{17.841} & 0.53 & 3.05 & Temsah & \multirow{2}{*}{$\begin{array}{c}\text { Employee } \\
\text { awareness of career } \\
\text { path }\end{array}$} \\
\hline & & 0.77 & 3.21 & Suez shipyard & \\
\hline \multirow[b]{2}{*}{0.000} & \multirow[b]{2}{*}{19.185} & 0.53 & 2.99 & Temsah & \multirow{2}{*}{$\begin{array}{c}\text { Career progression } \\
\text { opportunity }\end{array}$} \\
\hline & & 0.84 & 3.19 & Suez shipyard & \\
\hline \multirow[b]{2}{*}{0.006} & \multirow[b]{2}{*}{7.814} & 0.43 & 2.96 & Temsah & \multirow{2}{*}{$\begin{array}{c}\text { Career path } \\
\text { development }\end{array}$} \\
\hline & & 0.61 & 3.50 & Suez shipyard & \\
\hline \multirow[b]{2}{*}{0.000} & \multirow[b]{2}{*}{14.012} & 0.56 & 2.96 & Temsah & \multirow{2}{*}{$\begin{array}{l}\text { Strategic direction } \\
\text { for top } \\
\text { management }\end{array}$} \\
\hline & & 0.79 & 3.27 & Suez shipyard & \\
\hline \multirow[b]{2}{*}{0.002} & \multirow[b]{2}{*}{10.03} & 0.65 & 2.91 & Temsah & \multirow{2}{*}{$\begin{array}{c}\text { Effective } \\
\text { information system } \\
\text { to future leaders }\end{array}$} \\
\hline & & 0.81 & 3.25 & Suez shipyard & \\
\hline \multirow[b]{2}{*}{0.002} & \multirow[b]{2}{*}{9.491} & 0.71 & 2.82 & Temsah & \multirow{2}{*}{$\begin{array}{c}\text { Creative and } \\
\text { innovative training }\end{array}$} \\
\hline & & 0.89 & 3.17 & Suez shipyard & \\
\hline \multirow[t]{2}{*}{0.168} & 1.916 & 0.65 & 2.88 & Temsah & \multirow{2}{*}{$\begin{array}{c}\text { Leadership } \\
\text { succession planning } \\
\end{array}$} \\
\hline & & 0.70 & 3.27 & Suez shipyard & \\
\hline
\end{tabular}

Table19

From the preceding table we can summarize the following :

- $\quad$ The researcher can accept the second main hypothesis because of the value of $\mathrm{F}$. 


\section{Research findings:}

1- The researcher can refuse the first main hypothesis and accept the alternative one by:

- Refuse the first sub hypothesis and accept the alternative one

- Refuse the second sub-hypothesis and accept the alternative one

- Refuse the third sub-hypothesis and accept the alternative one

- Refuse the forth sub-hypothesis and accept the alternative one

2- Accept the second main hypothesis.

\section{General findings:}

The data has been collected from all levels of management in Temsah company and Shipyard Company through questionnaire to collect the sample opinions and attitude which serve the research topic and this to test the hypotheses in addition to make some interviews and this according to the following: Questionnaire : the questionnaire was designed to know the employees attitude at both Temsah and Shipyard companies at Egypt and the questionnaire formulated to conclude all the research variables which classified into 2 sections :

First part: questions related to career path planning indicators and consist of 20 statement. Second part: questions related to preparing future leaders and consist of 20 statement. Interviews: the researcher held interviews to analyze the questionnaire to

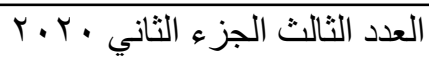

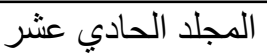


understand interviewees' responses and get some information, data, notes and opinions from interviewees.Analytical study: questionnaire was collected, classified and categorized to be analyzed and explained to summarize the result and recommendations. According to the study there are two main hypotheses the first was refused and the second was accepted.

\section{Reference}

D Śmiechowski, Young Leaders of the City of the Future, IOP Conference Series: Earth and Environmental Science, 2019

D. D. Warrick, The Urgent Need to Educate Present and Future Leaders in Organization Development and Change, OD PRACTITIONER

Daniel Spurk, Simone Kauffeld, Luisa Barthauer, Nora S.R. Heinemann , Fostering networking behavior, career planning and optimism, and subjective career success: An intervention study, Journal of Vocational Behavior , 87 (2015) 134-144

Dinah Payne ,Marek Pawlak and Sathiadev Mahesh, The Moral Development Index of Future Business Leaders: A Study on the Impact of Changes in Economic Systems and Gender, Journal of Business and Management, 24 (1), 2018, 50-79

Goonaseelan Pillai, Kelly Chibale' Edwin C. Constable, Akiko N. Keller' Marcelo M. Gutierrez, Fareed Mirza, Christian Sengstag, Collen Masimirembwa, Paolo Denti, Gary Maartens, Michèle Ramsay, Bernhards Ogutu, Eyasu Makonnen, Richard Gordon, Carlos Gil Ferreira, Fernando Alberto Goldbaum, Wim M. S. Degrave, Jonathan Spector, Brigitta Tadmor and Hedwig J. Kaiser' The Next Generation Scientist program: capacity-building for future scientific leaders in lowand middle-income countries , 2019 
Janice Waddell*, Karen Spalding, Genevieve Canizares, Justine Navarro, Michelle Connell, Sonya Jancar, Jennifer Stinson and Charles Victor, Integrating a Career Planning and Development Program into the Baccalaureate Nursing Curriculum: Part I. Impact on Students' Career Resilience, Int. J. Nurs. Educ. Scholarsh. 2015; 12(1): 163-173

Jasminka Samardžija,,Joseph Kevin Walker, and Vanda Bazdan, CAREER DEVELOPMENT AND PERSONAL SUCCESS PROFILE OF STUDENTS - FOLLOWERS AND STUDENTS - POTENTIAL FUTURE LEADERS: THE CASE OF RIT CROATIA , Journal of Contemporary Management Issues , 2. 6. 2017

Lea Ranacher, Kathrin Höfferer, Miriam Lettner, Franziska Hesser, Tobias

Stern, Romana Rauter, Peter Schwarzbauer, What would potential future opinion leaders like to know? An explorative study on the perceptions of four wood-based innovations, Journal of Land Management, Food and Environment, Volume 69, Issue 1

Lucija Andre $^{\mathrm{a}, \square}$, Thea T.D. Peetsma' Annelies E.M. van Vianen, Joost Jansen in de Wal, Danijela S. Petrović, Tomislav Bunjevac' Motivated by future and challenges: A cross-cultural study on adolescents' investment in learning and career planning, Journal of Vocational Behavior, Journal of Vocational Behavior 110 (2019) 168-185

Pestana JV and Codina N (2019) Being Conscious of One's Own Heroism:

An Empirical Approach to Analyzing the Leadership Potential of

Future CEOs. Front. Psychol. 9:2787. doi: 10.3389/fpsyg.2018.02787

Ralph Tench, Lucy Laville, Juliane Kiesenbauer, "Exploring the Magic of Mentoring: Career Planning for the Public Relations Profession" In The Management Game of Communication. Published online: 26 Aug 2016; 205-223. 
Ruth Bridgstock, Michelle Grant-Iramu and Alan McAlpine, Integrating career development learning into the curriculum: Collaboration with the careers service for employability, Journal of Teaching and Learning for Graduate Employability, 10(1),

Sylke Meyerhuber, Theme-Centered Interaction for Educating Future Leaders. Applied Social Psychology for Teaching Academics to Act Socially Sustainably in Organisations

Ulrike Fasbender' Anne M. Wöhrmann' Mo Wang and Ute-Christine Klehe' Is the future still open? The mediating role of occupational future time perspective in the effects of career adaptability and aging experience on late career planning, Journal of Vocational Behavior, Journal of Vocational Behavior 111 (2019) 24-38 Vol. 49 No. 32017 